\title{
'Florida White Ruffles' Caladium - A University of Florida Cultivar ${ }^{1}$
}

\author{
Baldwin D. Miranda, G.J. Wilfret, and B.K. Harbaugh ${ }^{2}$
}

Caladium [Caladium bicolor (Ait.) Vent., syn. Caladium x hortulanum Birdsey, Araceae Juss.] are popular foliage plants possessing great diversity in the shapes, sizes, and colors of their leaves. They commonly are sold as potted plants in the florist trade, as tubers for use in landscapes or home gardens, or as bedding plants for late spring or early summer (Harbaugh and Tjia, 1985). Although more than 1500 named cultivars have been introduced during the past 100 years (Hayward, 195), only 90 were found to be in commercial production in 1998 (Bell and Wilfert, 1998).

Most of the commercial tubers produced are utilized by potted plant growers in either 10- or 15-cm containers (D. Bates, personal communication). Many popular cultivars require excision of dominant buds (de-eyeing) on the tuber in order to produce an attractive container-grown plant. Bud excision eliminates apical dominance, resulting in greater leaf production and reduced plant height (Evans et al., 1992), but is a costly,

labor-intensive procedure. Tubers of 'Florida White Ruffles' produce attractive, compact, lance-leaf plants with numerous leaves (Fig. 1) without requiring bud excision. Excellent sun tolerance enhances this cultivar's potential for use as a border plant. Also, its size and slightly ruffled leaves can be desirable characteristics for combination plantings of caladium cultivars with differing foliar and growth habit characteristics.

\section{Origin}

'Florida White Ruffles', derived from a cross between the popular caladium cultivars 'Aaron' and 'Red Frill', initially was evaluated in 1985 as GC85-290. Ancestry of both parents is unknown. 'Aaron', a white cultivar with heart-shaped leaves, was selected as the female parent because of its vigor, tuber yield, and excellent sun tolerance. 'Red Frill', a red-lance-leaf cultivar, was selected because of its intermediate growth habit and ability to produce many bright red leaves. Tubers were propagated on fumigated EauGallie fine sandy soils at the Gulf Coast Research and Education Center (REC) Bradenton and were hot-water treated for nematode control (Rhodes, 1964).

1. This is document ENH959, a publication of the Environmental Horticulture Sciences Department, Florida Cooperative Extension Service, Institute of Food and Agricultural Sciences, University of Florida. Please visit the EDIS Website at http://edis.ifas.ufl.edu.

2. Baldwin D. Miranda, post doctoral researcher, Gulf Coast Research and Education Center- Bradenton; G.J. Wilfret, professor, Gulf Coast Research and Education Center - Bradenton; B.K. Harbaugh, professor, Gulf Coast Research and Education Center - Bradenton, Cooperative Extension Service, Institute of Food and Agricultural Science, University of Florida, Gainesville, FL 32611 


\section{Description}

Descriptions of color (e.g. RHS 147A) for plant parts are based on comparison with the Royal Horticultural Society's color chart (Royal Horticultural Society, 1986).

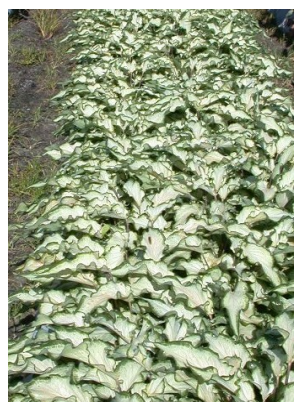

Figure 1. Trial row of 'Florida White Ruffles'. Credits: GCREC-Bradenton

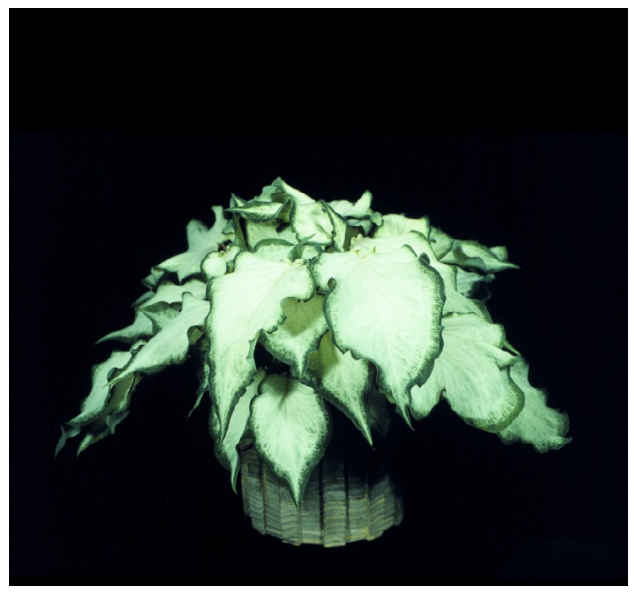

Figure 2. Potted example of 'Florida White Ruffles' caladium. Credits: GCREC-Bradenton

'Florida White Ruffles' plants grown for 7 months were $34-50 \mathrm{~cm}$ tall. Jumbo tubers were multi-segmented, 6.4-8.9 cm in diameter, bearing 6-8 dominant buds. Tuber surfaces are brown (RHS 200B), with the cortical area yellow-orange (RHS 20D). Leaves are saggitate-lanceolate, $19-25 \mathrm{~cm}$ long and 7-9 $\mathrm{cm}$ wide, slight undulate with greyed-white (RHS 156B) penniform venation. The upper surface has dark-green (RHS 139A) margins to $8 \mathrm{~mm}$ wide with a white (RHS 155C) clear center. Irregular greenish-white mottling (RHS 157B) parallels the margin. A 1-mm greyed-purple line (RHS 185A) is present on the basal leaf collar at the petiole apex. The undersurface has greyed-green (RHS 191A) margins with white (RHS 155B) veins. Petioles are a densely speckled brown (RHS 200D) and 3-5 $\mathrm{mm}$ in diameter.
Plants used for describing color were grown in $15-\mathrm{cm}$ diameter containers in a $40 \%$ shaded greenhouse from 2.54-cm-diameter tubers. Buds do not need to be excised for optimum performance.

\section{Performance}

'Florida White Ruffles' was evaluated for tuber production at the Gulf Coast REC-Bradenton, FL, during 1996, 1998, 1999, and 2000. The soil was EauGallie fine sand with $1 \%$ organic matter and a $\mathrm{pH}$ of 6.2. Plants were grown in a plastic-mulched raised-bed system maintaining a constant water table with seep irrigation (Geraldson et al., 1965). Ground beds were fumigated 3 weeks before planting with a mixture of $67 \%$ methyl bromide and $33 \%$

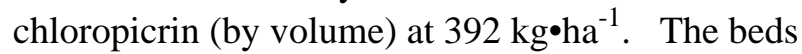
were $91 \mathrm{~cm}$ wide and $20 \mathrm{~cm}$ high with $2.54-\mathrm{cm}$ caladium seed pieces planted $15 \mathrm{~cm}$ apart in three rows spaced $15 \mathrm{~cm}$ apart. Osmocote $18 \mathrm{~N}-2.6 \mathrm{P}-10 \mathrm{~K}$ 8-9 month controlled-release fertilizer (Osmocote 18-6-12, Scotts Co., Marysville, $\mathrm{OH}$ ) was applied to the bed surface at the time of fumigation with $\mathrm{N}$ at

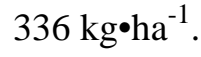

Plots were organized in a randomized complete-block design consisting of three replications. An analysis of variance combined over years was conducted in order to compare the performance of 'Florida White Ruffles' to several commercial lance-leaf cultivars (Tables 1 and 2).

Marketable tuber weight of 'Florida White Ruffles' was lower than 'White Wing' and 'Jackie Suthers' but much higher than 'Pink Gem'. However, the production index, an indicator of economic value of the tuber crop, was greater for 'Florida White Ruffles' than 'Jackie Suthers' and 'Pink Gem', and was similar to 'White Wing'. The production index reflects the crop value as prices change from year to year or grower to grower, but the differences between grades usually remain constant (Harbaugh and Overman, 1983). The favorable production index value of 'Florida White Ruffles' resulted from producing a high number of marketable tubers, well distributed in valuable grades. The marketable number of tubers produced by 'Florida White Ruffles' was higher than 'White Wing' and 'Pink Gem', and similar to 'Jackie Suthers'. 'Florida White 
Ruffles' produced a similar percentage of tubers in each grade as 'White Wing', while producing a greater percentage of jumbo tubers than 'Jackie Suthers'. 'Florida White Ruffles' produced a similar percentage of tubers in each grade as 'White Wing', while producing a greater percentage of jumbo tubers than 'Jackie Suthers' and 'Pink Gem' and a greater percentage of mammoth tubers than 'Pink Gem'. Lower marketable tuber weight for 'Florida White Ruffles' relative to the major white lance-leaf cultivars 'White Wing' and 'Jackie Suthers' resulted from producing less mass per tuber rather than fewer tubers.

Landscape performance of cultivars grown under full-sun conditions was evaluated in 1996, 1998, and 1999 (Table 3) on the same plots used for evaluating tuber production. Plant height, number of leaves, and foliar characteristics were recorded months after planting. 'Florida White Ruffles' plants were shorter than either 'White Wing' or 'Jackie Suthers' but taller than 'Pink Gem'. 'Florida White Ruffles' produced a superior number of leaves that were narrower than the commercial cultivars and exhibited excellent sun tolerance. The combination of numerous leaves on short plants results in plants with a very desirable compact appearance.

'Florida White Ruffles' tubers were forced in $10-\mathrm{cm}$ containers and growth was compared to commercial cultivars in 1998 (Table 4). The root medium contained 3 sedge peat : 1-1/2 coarse horticultural vermiculite : 1 sand (by volume) amended with (in $\mathrm{kg} \bullet \mathrm{m}^{-3}$ ) 3 dolomitic lime, 3 calcitic lime, 3 single superphosphate, 0.6 micronutrient mixture (Micromax, Scotts Co.) and 1.8 14N-6.1P-11.6K 3-4 months controlled-release fertilizer (Osmocote 14-14-14, Scotts Co.). Both studies were conducted in a glasshouse with $40 \%$ light exclusion during the summer in Bradenton, FL. Average daily temperatures were approximately $32^{\circ} \mathrm{C}$ day $/ 21^{\circ} \mathrm{C}$ night during the experiment. Plant height, number of leaves, and foliar characteristics were recorded 7 weeks after planting.

Plants of 'Florida White Ruffles' were more compact than 'White Wing' and similar to 'Jackie Suthers' and 'Pink Gem'. Leaf production of 'Florida White Ruffles' was superior to 'White Wing' and 'Jackie Suthers', as was observed in landscape-grown plants under full-sun conditions (Table 3). Leaf length and width was similar for the three white cultivars. 'Pink Gem' produced a similar number of leaves as 'Florida White Ruffles' and leaf length was shorter than white cultivars. Potted plant producers desire cultivars that are compact, have numerous leaves, and can be forced without excising dominant buds. 'Florida White Ruffles' possess all these attributes that facilitate production of full, attractive container plants.

'Florida White Ruffles' is intended for forcing in containers of 10 - to $20-\mathrm{cm}$ diameter and for use in shady to full-sun locations in the landscape. This new, white-strap cultivar offers advantages to both tuber and container producers. Although extensive research and evaluations have been performed on small acreages of this cultivar, tuber producers are encouraged to plant only limited quantities of 'Florida White Ruffles' until they have gained experience in production. Standard postharvest treatment of tubers is recommended and preplant hot-water treatment is encouraged to prolong the life of the tubers.

\section{Availability}

The Florida Agricultural Experiment Station has applied for a patent for 'Florida White Ruffles', and production of this cultivar is to be with a licensing agreement with Florida Foundation Seed Producers, Inc., P.O. Box 309, Greenwood, FL 32443. Information on tuber availability and propagation agreements can be obtained from the Florida Foundation.

\section{Literature Cited}

Bell, M.L. and G.J. Wilfert. 1998. Survey of Caladium Tuber Producers for Acreage of Cultivars Grown. Proc. Fla. State Hort. Soc. 111:32-34.

Evans, M.R., G.J. Wilfert, and B.K. Harbaugh. 1992. Caladiums as Potted and Landscape Plants. IFAS, Univ. of Florida Agr. Ext. Serv. Circ. 1060.

Geraldson, C.M., A.J. Overman, and J.P. Jones. 1965. Combination of High Analysis Fertilizers, Plastic Mulch and Fumigation for Tomato Production 
on Old Agricultural Land. Proc. Soil and Crop Sci.

Soc. Fla. 25:18-24.

Harbaugh, B.K. and B.O. Tjia. 1985.

Commercial Forcing of Caladiums. IFAS, Univ. of

Fla. Agr. Ext. Serv. Circ. 621.

Harbaugh, B.K. and A.J. Overman. 1983.

Evaluation of Fertilizer Types and Rates on Caladium

xhortulanum Birdsey Candidum Tuber Production in

Muck and Sandy Soil Management Systems. Proc.

Fla. State Hort. Soc. 96:250-254.

Hayward, W. 1950. Fancy-leaved Caladiums.

Plant Life 6:131:142.

Rhodes, H.L. 1964. Effect of Hot Water

Treatment of Seed Tubers and Soil Fumigation for

Control of Root Knot on Yield of Caladiums. Plant

Dis. Rptr. 8:568-571.

Royal Horticultural Society. 1986. RHS Colour

Chart. Royal Hort. Soc., London. 
Table 1. Tuber weights and the production index for caladium cultivars harvested in 1996, 1998, 1999, and 2000. Values presented are means of 3 replications with 30 propagules per $1.2-\mathrm{m}^{2}$ plot per year, averaged over 4 years.

\begin{tabular}{|c|c|c|c|c|c|}
\hline \multirow[b]{2}{*}{ Cultivar } & \multicolumn{4}{|c|}{ Tuber wt (g) } & \multirow[b]{2}{*}{$\begin{array}{l}\text { Production } \\
\text { index }\end{array}$} \\
\hline & Marketable & Seed & Total & Mean $^{2}$ & \\
\hline Florida White Ruffles & 2649 & 96 & 2745 & 68 & 100 \\
\hline Jackie Suthers & 3261 & 116 & 3377 & 91 & 89 \\
\hline Pink Gem & 1474 & 151 & 1625 & 46 & 62 \\
\hline White Wing & 3170 & 99 & 3269 & 88 & 98 \\
\hline $\operatorname{LSD}(a=0.05)$ & 326 & 50 & 324 & 7 & 10 \\
\hline \multicolumn{6}{|c|}{$\begin{array}{l}{ }^{z} \text { Mean }=\text { Marketable weight/marketable number. } \\
{ }^{y} \text { The production index is an indicator of economic value of crop calculated as: } N(\text { No. } 2 s)+2 N \text { (No. } \\
1 s)+4 N(\text { Jumbo) }+6 N \text { (Mammoth) }+6 N \text { (Super Mammoth); where } N=\text { number of tubers in each } \\
\text { grade. }\end{array}$} \\
\hline
\end{tabular}

Table 2. Tuber grade distribution of caladium cultivars harvested in 1996, 1998, 1999, and 2000. Values presented are means of 3 replications of 30 propagules per $1.2-\mathrm{m}^{2}$ plot per year, averaged over 4 years.

\begin{tabular}{|c|c|c|c|c|c|c|}
\hline \multirow[b]{2}{*}{ Cultivar } & \multicolumn{5}{|c|}{ Marketable tubers by grade ${ }^{z}(\%)$} & \multirow[b]{2}{*}{$\begin{array}{l}\text { Marketable } \\
\text { tubers (no.) }\end{array}$} \\
\hline & $\begin{array}{c}\text { Super } \\
\text { Mammoth }\end{array}$ & Mammoth & Jumbo & No. 1 & No. 2 & \\
\hline Florida White Ruffles & 0 & 6 & 26 & 47 & 21 & 39 \\
\hline Jackie Suthers & 1 & 7 & 18 & 1 & 33 & 37 \\
\hline Pink Gem & 0 & 1 & 11 & 45 & 44 & 34 \\
\hline White Wing & 0 & 8 & 30 & 44 & 18 & 36 \\
\hline $\operatorname{LSD}(a=0.05)$ & 1 & 3 & 5 & 8 & 8 & 3 \\
\hline
\end{tabular}


Table 3. Plant performance after 7 months for caladium cultivars grown in full sun from $2.5-\mathrm{cm}$ tubers in 1996, 1998, and 1999. Values presented are means of 3 replications with 3 plants measured per plot per year, averaged over 3 years.

\begin{tabular}{|lcccc|}
\hline \hline & & & \multicolumn{2}{c|}{ Leaf } \\
\cline { 4 - 5 } Cultivar & $\begin{array}{c}\text { Plant ht } \\
\text { (cm) }\end{array}$ & $\begin{array}{c}\text { Leaves } \\
\text { (no.) }\end{array}$ & $\begin{array}{c}\text { Length } \\
\text { (cm) }\end{array}$ & $\begin{array}{c}\text { Width } \\
\text { (cm) }\end{array}$ \\
\hline Florida White Ruffles & 42 & 4 & 22 & 8 \\
Jackie Suthers & 53 & 16 & 22 & 14 \\
Pink Gem & 32 & 17 & 17 & 11 \\
White Wing & 54 & 14 & 26 & 16 \\
LSD $(\mathrm{a}=0.05)$ & 4 & 5 & 2 & 1 \\
\hline \hline
\end{tabular}

Table 4. Plant performance after 7 weeks for caladium cultivars grown from No. 1 tubers in 10-cm containers in a $40 \%$ shaded glasshouse, 1998. Values presented are means of 6 plants with one No. 1 ( $>3.8<6.4 \mathrm{~cm}$ diameter) intact tuber planted per container.

\begin{tabular}{|lcccc|}
\hline \hline & & & \multicolumn{2}{c|}{ Leaf } \\
\cline { 4 - 5 } Cultivar & $\begin{array}{c}\text { Plant ht } \\
\text { (cm) }\end{array}$ & $\begin{array}{c}\text { Leaves } \\
\text { (no.) }\end{array}$ & $\begin{array}{c}\text { Length } \\
(\mathbf{c m})\end{array}$ & $\begin{array}{c}\text { Width } \\
(\mathbf{c m})\end{array}$ \\
\hline Florida White Ruffles & 20 & 36 & 15 & 8 \\
Jackie Suthers & 23 & 29 & 15 & 9 \\
Pink Gem & 18 & 40 & 12 & 8 \\
White Wing & 25 & 23 & 16 & 9 \\
LSD $(\mathrm{a}=0.05)$ & 4 & 7 & 2 & 2 \\
\hline \hline
\end{tabular}

